\title{
PEMBUATAN TAHU RUMAHAN KHAS LEDOK KULON
}

\author{
Oleh: \\ Prasetyo Adhi Bintoro, Putri Maselia, Anjas Wahyu Kintoko, \\ Anassabri Akbar Defanda, Ade Fitriyanto, Fajar Ramadhan, Meilia Kartika, Ummi Aulia \\ Septiani, Debby Elvionita \\ Universitas Ahmad Dahlan Yogyakarta
}

\begin{abstract}
Abstrak
Tahu merupakan salah satu bahan makanan pokok di Indonesia. Tahu juga merupakan makanan yang mengandung banyak gizi dan cukup mudah untuk diproduksi. Untuk membuat tahu, bahan-bahan yang dibutuhkan hanya berupa kacang kedelai. Tidak heran jika di Kelurahan Ledok Kulon mayoritas warganya adalah pembuat tahu. Para pembuat tahu di Ledok Kulon termasuk dalam kategori Usaha Kecil dan Menengah (UKM). Cara pembuatan tahu pun masih dengan cara yang sederhana, sehingga peran individu dalam hal ini pekerja sangatlah besar didalam proses pembuatannya.
\end{abstract}

Kata Kunci:usaha kecil, pemberdayaan, desa

\begin{abstract}
Tofu is one of main meals in Indonesia. Tofu also has a lot of nutrients and easy enough to be producted. Soya is the main ingredient to make a tofu. No wonder if people in Ledok Kulon district mostly has a tofu factory which is belong to home production. The production in those factories are still traditional, so that the worker skill is important during the production.
\end{abstract}

Kata Kunci:small businnes, vilage, enpowering,

\section{A. PENDAHULUAN}

\section{Latar Belakang}

Tahu adalah makanan yang bahan bakunya berasal dari kedelai yang dihancurkan menjadi bubur. Setiap harinya kita mudah mendapatkan tahu, bahkan di Kelurahan Ledok Kulon sangat mudah sekali mencari tahu karena di daerah ini mayoritas warganya adalah bekerja sebagai pembuat tahu. Tahu di Ledok Kulon ini dikenal dengan sebutan tahu pong. Cara pemanfaatan tahu cukup mudah, hanya digoreng saja sudah dapat dinikmati dan rasanya pun gurih, selain digoreng untuk lauk, tahu juga dapat diolah menjadi makanan lain seperti bacem, oseng, tahu crispy dan lain-lain. Tahu juga memiliki gizi yang cukup tinggi dan juga mengandung beberapa macam asam amino yang dibutuhkan oleh tubuh manusia. Bagi para pembuat tahu, usaha ini dapat dijadikan sebagai salah satu alternatif peluang kerja dengan modal yang tidak begitu mahal serta cara pembuatannya yang cukup mudah.

\section{Rumusan Masalah}

Rumusan masalah pada artikel ini adalah:

1) Sejak kapan tahu ledok berdiri?

2) Bagaimana proses pembuatan tahu kedelai khas Ledok Kulon?

3) Apa saja bahan baku, bahan pembantu, serta peralatan dalam proses pembuatan tahu? 


\section{Tujuan}

Tujuan pada artikel ini adalah:

1) Untuk menambah wawasan tentang cara pembuatan tahu khas Ledok Kulon.

2) Untuk memberikan informasi kepada masyarakat bahwa mayoritas warga di Kelurahan Ledok Kulon bekerja sebagai pembuat tahu.

\section{Manfaat}

Adapun manfaat yang dapat diperoleh dari artikel ini adalah:

1) Manfaat Teoritis

a. Memberikan masukan dalam khasanah pengetahuan dalam bidang pertanian.

b. Memperkaya perkembangan pertanian khususnya dalam pembuatan tahu kedelai.

2) Manfaat Praktis

a. Bagi pembaca diharapkan dapat memahami dan mengetahui bagaimana cara pembuatan tahu khas Ledok Kulon.

\section{B. KERANGKA TEORI}

\section{Sejarah Tahu}

Tahu dibuat dari kacang kedelai yang difermentasikan dan dambil sarinya. Tahu berasal dari negara China. Tahu adalah kata serapan dari bahasa Hokkian, tauhu (hanyu pinyin: doufu) yang secara berarti "kedelai yang difermentasi". Di Jepang dikenal dengan nama tofu. Dibawa para perantau China, makanan ini tersebar ke Asia Timur dan Asia Tenggara dan akhirnya ke seluruh dunia. Tahu pertama kali muncul di Tiongkok sejak zaman Dinasti Han, sekitar 2200 tahun yang lalu. Penemunya adalah Liu An yang merupakan seorang bangsawan, cucu Kaisar Han Gaozu, Liu Bang, yang mendirikan Dinasti Han. Liu An adalah ilmuan dan filosof, penguasa dan ahli politik. Ia tertarik pada ilmu kimia dan Meditasi Tadiom. Para ahli sejarah berpendapat bahwa kemungkinan besar Liu An memadatkan tahu dengan nigari atau air laut dan menjadi kental seperti tahu saat ini.

\section{Teori-Teori Tentang Tahu}

Ada beberapa teori tentang bagaimana pada awalnya tahu terbentuk:

a. Teori pertama kemungkinan besar proses penggumpalan tahu terjadi seara kebetulan. Apabila membaut sup dari puree kedelai, biasanya harus diberi bumbu. Bila sup tersebut diberi garam, kemungkinan besar mengandung nigari (garam alami). Dengan adanya garam nigari, maka penggumpalan tahu akan terjadi, garam yang sengaja ditambahkan ternyata dapat menggumpalkan tahu. Para tukang masak kemudian mengambil ampas tahu, agar mendapat tahu yang lebih lembut dengan tekstur yang indah. Tahap berikutnya adalah dengan pengepresan, membantu makanan lebih tahan dan segar dalam waktu yang cukup lama.

b. Teori kedua mengusulkan bahwa karena tidak menernakkan sapi atau kambing untuk produksi susu, kemungkinan besar masyarakat China tidak familiar dengan cara menggumpalkan susu atau proses penggumpalan secara umum. Karena alasan 
Diterbitkan oleh Lembaga Pengabdian kepada Masyarakat

Universitas Ahmad Dahlan Yogyakarta

tersebut, kemungkinan besar mereka belajar dari orang India di daerah Cina selatan atau dari Mongolia bagian utara China. Kedua negara tersebut biasa membuat gumpalan susu dan keju. Teori teknologi import dari negara tetangga dianggap masuk akal karena Cina sangat menggemari delicacy yang beraroma ringan seperti "shark pin", sarang burung wallet, dan teripang yang juga di import dari negara lain.

Kata tofu atau tahu muncul pertama kali dalam sejarah China sekitar 800 tahun kemudian. Dikatakan bahwa Budhi Dharma, yang hidup di China dari tahun 500 sampai 528 telah mendirikan sekolah Chinesse Ch'an (Zen), dan dalam ajarannya telah melibatkan tahu dalam Dharma Combat. Untuk memperdalam pertanyaan mengenai cara-cara atau jalan Budha, Budi Dharma kemudian mengagungkan dan merefleksikan tahu sebagai sumber dari sesuatu yang sederhana, sifat jujur, jalan alam pintas, dan mencerminkan warna sebagai jubbah yang putih dan agung. Prasati tertua yang menyebut tofu adalah Saiinoku, yang ditulis sewaktu Dinasti Sung (960-1127), lebih dari 100 tahun setelah penemu tahu itu sendiri.

Banyak buku kuno atau prasasti pada zaman itu menunjukan karya yang ditulis sekitar 60 sampai 100 BC, yang berisi cerita Lord Liu An dan Tofu jaman itu. Di bukubuku yang diterbitkan di jaman Dinasti Sung, terdapat deskripsi atau uraian yang menunjukan bahwa tahu sering disajikan untuk santapan raja-raja di zaman itu. Tofu atau tahu menebar ke Jepang pada abad ke delapan dan kemungkinan dibawa dari daratan China oleh beberapa pendeta Budha (Bhiksu) yang berkelana antara Jepang dan China.

Masuknya tahu ke Jepang melalui jalur keluarga istana, para politisi dan ekonomi yang saat itu banyak berhubungan antara China dari Jepang. Para Bhiksu Budha sendiri memakan tofu setiap harinya. Di daerah sekitar Candi Budha yang besar terdapat kedaikedai tahu dan diorganisasi atau dikelola oleh para Bhiksu Budha. Di Jepang khususnya di zaman Kamakura (1185-1333) terjadilah gerakan besar-besaran untuk mempopulerkan tahu diantara penganut agama Budha bagi masyarakat Jepang. Dari Kamakura berkembang merambat ke Kyoto dan dari Kyoto menyebar ke seluruh negeri Jepang. Karena masyarakat Jepang mengikuti kehidupan para pemeluk agama Budha, yaitu menghindarkan diri dari konsumsi daging "dari ternak yang berkaki empat", maka kehadiran tahu tentu saja disambut dengan baik sebagai sumber makanan kaya protein dan gizi yang murah dan lezat rasanya.

Dari Jepang, tahu berkembang dan maju sehingga timbullah inovasi baru di bidang produksi tahu termasuk di dalamnya: tahu beku kering (dried frozen tofu), age, grilled tofu, dan nigari kinogushi. Bersamaan dengan menyebarnya tahu di Jepang, sifat dasar tahu setahap mengalami perubahan. Ditangan para ahli seni masak dan keterampilan, tahu yang diproduksi semakin lebih lunak, lebih putih dan dengan cita rasa yang lebih enak. Namun demikian tahu yang diproduksi di kawasan pedesaan ternyata masih tetap mempertahankan tiingkat kepadatan yang lama serta kaya cita rasa seperti tahu dari daratan Tiongkok. Ketika seorang Zen Master China yang bernama Ingen, tiba di Jepang di tahun 1661, ia sangat terperanjat saat menemukan tofu yang tidak lagi seperti tahu yang terdapat di China saat ia meninggalkan China. 


\section{METODOLOGI PENELITIAN}

\section{Tempat Dan Waktu}

Kegiatan ini dilaksanakan mengikuti lamanya masa KKN, yaitu satu bulan, yang dimulai dari tanggal 1 Agustus sampai dengan 30 Agustus 2017. Kegiatan yang dilaksanakan meliputi persiapan, pengumpulan data, menganalisis data, dan penyusunan laporan. Waktu dan kegiatan ini bersifat fleksibel. Kegiatan ini dilaksanakan di RT 06 RW 03 Kelurahan Ledok Kulon, Kabupaten Bojonegoro, Provinsi Jawa Timur.

\section{Teknik Pengumpulan Data}

Karya ilmiah ini menggunakan metode pengumpulan data pustaka (study literature). Telah pustaka digunakan untuk mendapatkan data.

\section{Teknik Analisis Data}

Setelah diperoleh data sesuai kebutuhan, selanjutnya diadakan proses analisis data. Dalam proses analisis data peneliti memaparkan tentang deskripsi pembuatan tahu Ledok Kulon. Dalam teknik analisis data ada beberapa tahapan, yaitu:

a. Pengumpulan Data

Data diperoleh melalui hasil wawancara, observasi, warga Ledok Kulon yang memiliki rumah industry tahu.

b. Reduksi Data

Melalui proses reduksi ini diharapkan untuk lebih mempertajam, mengarahkan, dan membuang data yang tidak diperlukan serta mengorganisasikannya sehingga mudah untuk dilakukan penarikan kesimpulan, kemudian dilanjutkan dengan proses verifikasi.

c. Penyajian Data

Penyajian data dalam laporan penelitian ini menggunakan analisis secara deskripstif.

d. Penarikan Kesimpulan

Penarikan kesimpulan dari penelitian ini adalah dengan melihat responden yang diteliti dan mempertanyakan hasil data yang diperoleh dari wawancara dengan berbagai narasumber.

\section{PEMBAHASAN}

\section{Alat dan Bahan}

Untuk membuat tahu kedelai, kita membutuhkan beberapa bahan dan peralatan, dimana bahan yang dibutuhkan untuk membuat tahu kedelai ada 2 macam, yaitu bahan baku dan bahan pembantu. Bahan baku yang digunakan adalah kedelai kuning, sedangkan bahan-bahan pembantunya adalah garam, kunyit, dan lain-lain.

a. Bahan baku

Bahan baku tahu kedelai yaitu kedelai kuning. Biasanya bahan baku ini sering diangap sepele sehingga produk tahu yang dihasilkan kurang memuaskan. Kedelai kuning adalah kedelai yang kulit bijinya berwarna kuning, putih, dan hijau. Apabila dipotong melintang maka akan memperlihatkan warna kuning pada irisan keeping 
bijinya. Kedelai kuning inilah yang yang digunakan sebagai bahan baku tahu. Bentuk biji kedelai juga bervariasi, yaitu tergantung pada kulitnya. Ada biji kedelai yang berbentuk bulat, agak gepeng, dan sebagian besar bulat telur.

\section{b. Bahan pembantu}

Tahu kedelai dibuat dengan cara mengendapkan protein dari kedelai dengan menggunakan bahan penggumpal. Bahan penggumpal yang digunakan biasanya sisoko (CaSO4). Sisoko ini berasal dari gips yang mengandung kalsium sulfat yang sudah dibakar dan ditumbuk halus menjadi tepung. Sisoko ini digunakan dengan mencampurkan bubuk kedelai yang sudah disaring. Selain itu juga menggunakan asam cuka (90\%) atau "biang" ataupun sari jeruk. Bila menggunakan bahan-bahan itu kita harus mengetahui dosis yang tepat, bila tidak tepat maka kemungkinan akan gagal dalam proses pembuatan tahu. Misalnya penggunaan asam cuka dengan dosis yang tidak pas kemungkinan besar rasa tahu menjadi masam. Begitu pula dengan penggunaan biang (sisa cairan setelah tahap pengendapan protein atau sisa cairan dari pemisahan gumpalan tahu yang dibiarkan semalam) juga memiliki resiko yang cukup tinggi. Misalnya apabila biang mengandung bakteri, maka tahu pun akan cepat membusuk.. Warna asli tahu adalah putih, namun ada juga yang berwarna kuning, yang berwarna kuning diberi campuran kunyit.

c. Peralatan

Peralatan yang digunakan antara lain adalah:

1) Tungku, digunakan untuk memasak bubur kedelai.

2) Timbangan, digunakan untuk menimbang bahan bahan yang digunakan untuk membuat tahu.

3) Panci, digunakan untuk merendam dan mengupas kulit kedelai.

4) Ember, digunakan untuk mencuci dan merendam kedelai.

5) Tampah, digunakan untuk menampi kedelai agar bersih dari kotoran.

6) Wajan, digunakan untuk mendidihkan bubur kedelai.

7) Penggiling tahu, digunakan untuk menggiling kedelai.

8) Penggiling batu, digunakan untuk menggiling kedelai sampai menjadi bubur.

9) Cetakan tahu, digunakan untuk mencetak tahu.

10) Kain mori, digunakan untuk alas cetakan tahu.

\section{Cara Pembuatan Tahu Kedelai}

a. Penyortiran dan pencucian

Rata-rata setiap harinya para pembuat tahu di Ledok Kulon menggunakan kurang lebih 10 kuintal kedelai. Sebelum digiling, biji kedelai harus disortir terlebih dahulu. Tujuan dari penyortiran adalah agar mendapatkan kedelai dengan kualitas yang baik dan terbebas dari kotoran. Selanjutnya biji yang sudah disortir kemudian dimasukan ke dalam ember yang berisi air mengalir, sehingga kotoran dapat terlepas. 
b. Perendaman

Selanjut adalah proses perendaman, kedelai direndam selama 6-12 jam. Perendaman dilakukan agar kedelai dapat menyerap air sehingga dapat lunak dan kulitnya mudah untuk dikupas. Cara untuk mengupas kulit kedelai adalah dengan diremas-remas dalam air.

c. Penggilingan

Kedelai yang sudah direndam lalu ditambah air panas dan di masukan kedalam alat penggiling. Cara penggilingannya adalah biji kedelai direndam air panas selama beberapa menit kemudian dimasukan ke dalam penggilingan yang digerakan generator. Biji-biji kedelai tergiling menjadi halus dan menjadi bubur putih yang kemudian ditampung dalam panic besar.

d. Pendidihan

Pendidihan bertujuan untuk menonaktifkan zat antinutrisi kedelai dan meningkatkan nilai cerna. Cara pendidihan ini adalah bubur kedelai dimasukan ke dalam wajan besar lalu dipanaskan diatas tungku, lalu diberi sedikit air, selama pendidihan maka akan keluar busa, sehingga perlu diaduk. Waktu untuk proses pendidihan ini kurang lebih 15-40 menit.

e. Penyaringan

Proses selanjutnya adalah bubur kedelai disaring agar diperoleh sari kedelai. Caranya adalah bubur kedelai diletakan diatas kain mori kasar yang ada di dalam panic, setelah itu kain mori ditutup lalu diletakan diantara penjepit papan kayu yang berada pada permukaan panic. Papan kayu diletakan sekuat-kuatnya agar semua air terperas semua. Proses penyaringan ini dapat dilakukan berulang kali. Selanjutnya sari kedelia yang masih hangat dan berwarna kuning ditambah dengan batu tahu atau air cuka sehingga timbu jonjot-jonjot putih. Penggumpalan ini berlangsung selama 10 menit agar mendapatkan protein yang sempurna.

f. Pencetakan

Cara pertama adalah dengan memisahkan air asam atau cuka dengan meletakan tampah diatas endapan kemudian ditekan. Setelah itu gumpalan protein dimasukan kedalam cetakan. Yang bagian bawahnya diberi kain mori, lalu ditutup dan diatasnya diberi pemberat, lalu tunggu sekitar 3 menit, jadilah tahu kemudian dipotong sesuai permintaan konsumen.

g. Perebusan

Langkah selanjutnya adalah tahu direbus lalu didiamkan dalam air rebusan sampai saatnya akan dijual. Tujuan dari perebusan ini adalah agar tahu tidak mudah basi.

Tahu memang identik dengan sapi, karena, ampas tahu (limbah padatnya) bisa dimanfaatkan sebagai pakan ternak. Semua sisa pembuatan tahu tidak sia-sia, melainkan bisa dimanfaatkan atau dijual. Kalau ampas tahu padat dipakai untuk pakan ternak, arang sisa kayu bakar biasanya dijual Rp25.000/karung. "Tapi biasanya 1 karung itu sisa pembakaran selama seminggu," kata salah seorang narasumber.

Bisa dibilang tahu Ledok menjadi warisan nenek leluhur mereka. Dia tidak tahu kapan Desa Ledok Kulon memulai usaha tahu. Karena, sejak tahun 1960-an, tahu sudah 
Diterbitkan oleh Lembaga Pengabdian kepada Masyarakat

Universitas Ahmad Dahlan Yogyakarta

ada di Ledok Kulon dan bisa dimakan warga Bojonegoro dan sekitarnya. "Ini bisnis utama keluarga kami. Tidak ada usaha lain.

\section{E. PENUTUP}

\section{Kesimpulan}

Berdasarkan hasil penelitian ini, dapat disimpulkan beberapa hal mengenai pembuatan dan pengembangan tahu ledok:

a. Usaha sentra industri tahu ini telah dijalankan oleh warga setempat sudah puluhan tahun bahkan ada yang usahanya merupakan usaha turun temurun dari mulai kakeknya terdahulu, sehingga telah memiliki agen-agen pendistribusian dari produk tahu yang diproduksinya. Pabrik ini menggunakan prinsip management keluarga, jadi pengelolanya adalah keluarga dari pemiliknya itu sendiri dan termasuk kedalam jenis perusahaan perseorangan karena pemiliknya hanya satu orang saja. Dan dalam pendistribusiannya masing-masing dari mereka sudah memiliki agen-agen atau pembeli tetap setiap harinya, seperti misal ada yang di beli oleh pedagang-pedangan sayur keliling, pedagang dipasar bahkan ada juga yang merangkap sebagai pedagang di pasar, jadi hasil produksinya tadi langsung mereka jual sendiri di pasar, karena kebetulan desa ini jaraknya lumayan dekat dengan pasar Kota Bojonegoro.

b. Pembuatan tahu ledok hingga saat ini masih belum jelas kapan pastinya tahu Ledok ini muncul, namun kebiasaan warga menyebutkan bahwa tahu ini memiliki ciri khas sendiri sehingga warga menyebutnya dengan sebutan tahu Ledok karena berasal dari Ledok Kulon.

c. Pembuatan tahu ledok memiliki ciri khas yang berbeda ditiap rumah industrinya namun tetap memiliki rasa yang khas.

\section{Saran}

Berdasarkan kesimpulan penelitian, maka penulis merekomendasikan berupa saran-saran sebagai berikut:

a. Pembuatan tahu ledok dapat dioptimalkan dan menjadi warisan kuliner khas bojonegoro yang memiliki ciri khas tersendiri.

b. Penjualan tahu ledok diharapkan dapat meluas hingga mancanegara.

c. Memperbanyak penyebaran informasi mengenai tahu ledok ini sehingga namanya dapat dikenal oleh masyarakat luas.

\section{DAFTAR PUSTAKA}

http://pkkkecamatanbojonegoro.blogspot.co.id/2016/08/home-industri-tahu-ledok-kulondi.html diakses tanggal 28 Agustus 2017 pukul 20.30 
